\title{
О СОСТАВЕ ПРОДУКТА РЕАКЦИИ ТЕЛОМЕРИЗАЦИИ ИЗОПРЕНА С УКСУСНОЙ КИСЛОТОЙ
}

A. ERM, is KALJURAND, $K$. LAATS. ISOPREENI JA AADIKHAPPE TELOMERISATSIOONIPRODUKTI KOOSTISEST

A. ERM, M. KALJURAND, K. LAATS. ON THE COMPOSITION OF THE ISOPRENE AND ACETIC ACID TELOMERIZATION PRODUCT

Во фракции $\alpha$-терпинеола, полученного при разгонке продукта реакции теломеризации изопрена с уксусной кислотой ['], содержался первичный спирт (пик 12 на хроматограмме, приведенной в [']), который отде-<smiles>C=CC(C)(C)CC(C)=CCO</smiles>

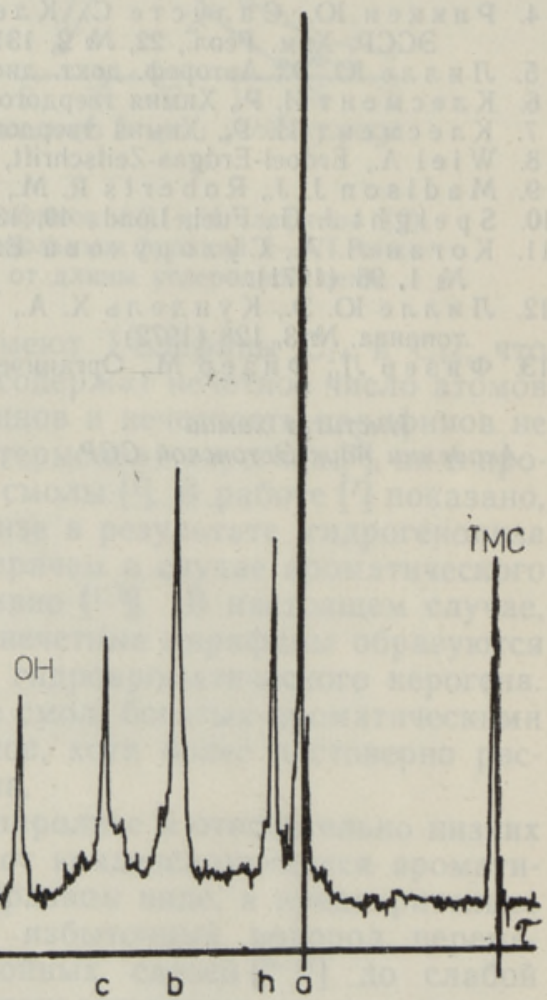

$\vdash a \rightarrow+e-t+d \rightarrow$

Спектр ПМР для 3,5,5-триметил-2,6-гептадиен-1-ола, снятый на универсальном спектрометре «Тесла Bs 487 В» при 80 Мгц. Обозначенйя химических сдвигов см. в таблице. 
лялся от $\alpha$-терпинеола фталированием в пиридине по методике, приведенной в [ ${ }^{2}$. Для выделенного продукта (чистота по данным ГЖХ $95 \%$, содержание $\alpha$-терпинеола $4 \%$, температура кипения $81-82^{\circ} / 5$ мм рт. ст., $\left.n_{D}^{20}-1,4726\right)$ в виде $15 \%$-ного раствора в четыреххлористом углероде с добавкой $1 \%$ тетраметилсилана в качестве внутреннего стандарта был снят спектр ПМР на универсальном спектрометре «Тесла Bs 487 В» при 80 Мгц (рисунок).

На основе спектральных данных, приведенных в таблице, исследуемому веществу предложена структура 3,5,5-триметил-2,6-гептадиен-1-ола, дан-

\begin{tabular}{c|c|c|c}
\hline Группа & $\begin{array}{c}\text { Количе- } \\
\text { ство } \\
\text { протонов }\end{array}$ & \multicolumn{2}{|c}{ Сигнал м. д. $\tau$} \\
\cline { 3 - 4 } & определен & рассчитан \\
\hline
\end{tabular}

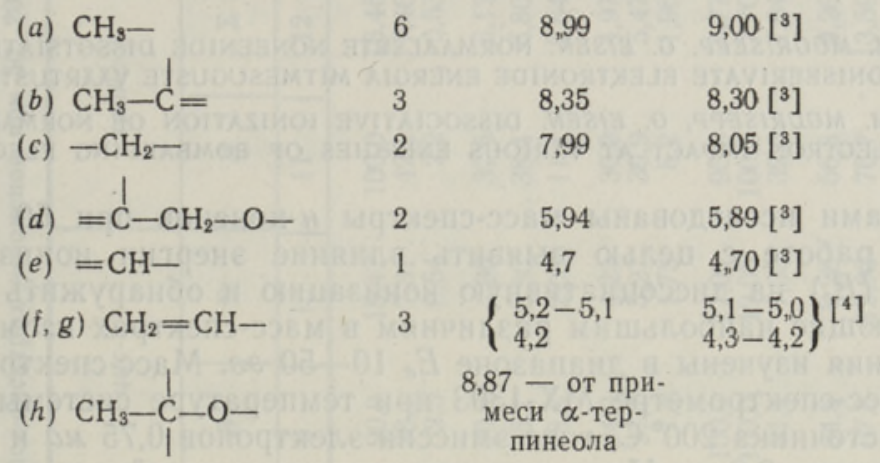

ные теоретического спектра которого также представлены в таблице. Это вещество, по-видимому, образуется в результате 1,4-присоединения кар-

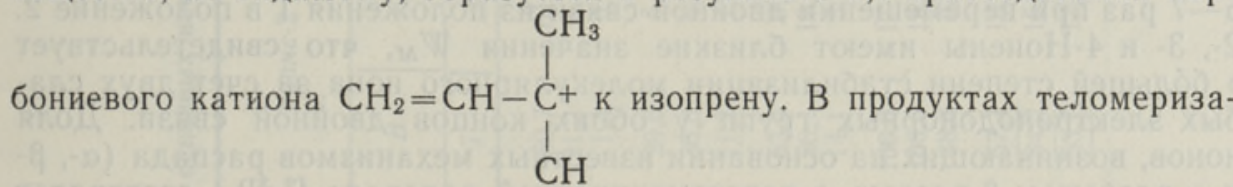
ции изопрена с уксусной кислотой, а также в продуктах теломеризации изопрена с его гидрохлоридами до настоящего времени не идентифицировано соединений, образующихся в результате присоединения вышеприведенного катиона.

Авторы благодарят Э. Липпмаа и М. Алла за возможность использования спектрометра «Тесла Bs 487 В» и за методические указания при работе с ним.

\section{ЛИТЕРАТУРА}

1. Э р м А., Л э э т с К., Изв. АН ЭССР, Хим. Геол., 16, 37 (1967).

2. Gil d e meister E., $\mathrm{H}$ of $\mathrm{f} \mathrm{m}$ a $\mathrm{n} \mathrm{n}$ Fr., Die ätherischen Ole, B. IIIa Akademie-Verlag; Berlin, 1960, S. 564.

3. An Introduction to Spectroscopic Methods for the Identification of Organic Compounds, ed. by F. Scheinmann, I, Pergamon Press, Oxford, 1970, p. 61 .

4. Э м сли Дж, Фине й Дж., С а ткли ф Л., Спектроскопия ЯМР высокого разрешения, 2, М., 1969 , с. 434. 